UDK 366.542:336.7

https://doi.org/10.18485/union_pf_ccr.2021.ch18

Prof. Williams C. Iheme*

\title{
RETHINKING THE EFFECTIVENESS OF CONSUMER PROTECTION POLICIES AND MEASURES IN THE FINANCIAL MARKETPLACE
}

\author{
"In the end, our financial system only works - our market \\ is only free - when there are clear rules and basic safeguards \\ that prevent abuse, that check excess, that ensure that \\ it is more profitable to play by the rules than to game the system."
}

Barack Obama

\begin{abstract}
This paper identifies and challenges the frequent practice of financial institutions in designing and selling complex financial products to consumers who are not able to fully comprehend them, thus unable to make informed decisions before consumption. Tricking consumers to inadvertently purchase complex financial products, generally causes them to suffer financial losses, which on aggregate, has negative ripple effects in society. The paper discusses the reasons financial institutions are motivated to sell complex financial products, and notes how their success in this regard is nourished by the inadequacies of regulatory systems, among other things. The law of contract is identified as aiding to create a fertile ground through its freedom of contract and caveat emptor ${ }^{2}$ rules that make the abuses of financial consumers often unnoticed or appreciated by regulators, thus requiring the former to largely pull themselves up by their own bootstraps. The paper points out the weaknesses in the typical policy measures against exploitation and the mangled rules of disclosure
\end{abstract}

* $\quad$ LLB, LLM, SJD., Associate Professor of Law, Jindal Global Law School.

e-mail: wciheme@jgu.edu.in; williamsiheme@gmail.com

My thanks go to the organizers and participants of the International Conference "The Protection of the Collective Interests of Consumers" organized in October 2020 by the Union University School of Law, in partnership with The Institute of Comparative Law, where a draft of this paper was presented. I am grateful to Dr. Joseph Nwobike SAN, Dr. Asress Gikay (Brunel University, London), Dr. Catalin Stanescu (University of Copenhagen) for providing me with feedback on the earlier drafts. The usual caveat applies.

1 Obama, B., Remarks by the President at Signing of Dodd-Frank Wall Street Reform and Consumer Protection Act, The White House, July 21, 2010, para. 21 (https://obamawhitehouse.archives.gov/the-press-office/remarks-president-signing-dodd-frank-wall-street-reformand-consumer-protection-act, 10. 8. 2020).

2 Hamilton, W. H., 1931, The Ancient Maxim Caveat Emptor, Yale Law Journal, Vol. 40, No. 8, pp. 1156-1160, (https://digitalcommons.law.yale.edu/cgi/viewcontent.cgi?article=3488\&context=ylj). 
which largely place the burden of comprehension of complex financial products on consumers notwithstanding the machinations of financial institutions toward diminishing comprehension: most financial information booklets are sprinkled heavily with financial terminologies and in complicated language whilst still satisfying the legal requirements of disclosure. The paper proposes a new form of disclosure rule based on the concepts of caveat venditor and contra proferentem, which respectively should require a financial institution's presentation of information against self-interest, and the unambiguous presentation of equal number of disadvantages alongside the advantages of the products they offer to their consumers. The paper further argues that the principal role of regulators and courts in the circumstance, should be to supervise and assess the level of compliance, and consequently issue on annual basis, a rated performance certificate which financial institutions must post conspicuously on their websites and places of business, and also incorporate same in the information leaflets wherein they described their products, so that consumers can know at a glance those financial institutions that are, or not consumer friendly.

Key words: financial consumers, disclosure, freedom of contract, caveat emptor, caveat venditor, shrouded products, regulatory capture.

\section{INTRODUCTION}

\subsection{CONSUMERS ARE STILL RELATIVELY 'NEW KIDS' IN THE FINANCIAL MARKETPLACE}

Before the $20^{\text {th }}$ century, credit borrowing was mainly for merchants, i.e., those in the business of buying and selling. ${ }^{3}$ If one was not a trader in goods and services, it was frowned upon if they borrowed credit merely for personal consumption. The stigma against credit borrowing by individuals was intense before the $20^{\text {th }}$ century, and in permissive instances, borrowing for personal consumption was left only as a last resort. The stigma against credit borrowing accounted for the stiff penalties against default in the era before the $20^{\text {th }}$ century: penalties ranging from stripping the debtor of their entire property, imprisoning them or in egregious cases, killing the debtor. ${ }^{4}$

The Industrial Revolution witnessed a high level production of goods and services through the aid of machines: more goods became available for sale, yet not many individuals could afford these goods on a cash-and-carry basis. The idea of consumer credit, especially sale credit, i.e., an arrangement in which an individual could enjoy the equitable or legal ownership of a property even though they were yet to fully pay for them at the time of acquiring possession, but with an agreement to repay fully at a future date, became one of the attractive ways for producers to match sales with the heightened capacity of production. ${ }^{5}$

3 Simpson, W. B., 1975, A History of the Common Law of Contract: The Rise of the Action of Assumpsit, New York, Oxford University Press, pp. 510-518.

4 Cornish, W. R., Clark G. N., 1989, Law and Society in England 1750-1950, London, Sweet \& Maxwell, Chap. 2; Cohen, J., 1982, History of Imprisonment for Debt and Its Relation to the Development of Discharge in Bankruptcy, Journal of Legal History, Vol. 3, No. 2, p. 153.

5 Tolmie, F., 2003, Corporate and Personal Insolvency, $2^{\text {nd }}$ ed., London, Cavendish Publishing, p. 15. 
After more than 250 years of experimenting to produce with machines, i.e., between the Industrial Revolution in 1760 and the $21^{\text {st }}$ century whereby credit use has become mainstream, individuals now have many reasons to interact with financial institutions: while these interactions are necessarily indispensable, the relationship between financial institutions and their financial consumers could still be likened to yoking a horse and an ass: the financial institution the horse; their customers, the ass. ${ }^{6}$ Since the 2008 financial crisis, consumer credit alongside the innumerable financial products in the market as well as the concomitant risks for consumers has increasingly become a topic for discussion. ${ }^{7}$ Nowadays, it has come to be largely appreciated that most of human activities cannot be sustained on a cash-and-carry basis: be it student loans, house mortgages, sale credits, loan credits, etc., these are avenues by which an individual can realize their full potentials without necessarily having all the financial resources needed for them in the outset. ${ }^{8}$ As Lusardi and Mitchell rightly pointed out, the uncountable number of financial products in the market could mean or imply that consumers of credit should be financially literate in order to make healthy, informed, and smart financial decisions, given that lack of such attributes could cause a consumer, and sometimes his family, to suffer financial distress. ${ }^{9}$ However, as Emmons opined, financial literacy is difficult to achieve by an individual that lacks some form of formal training in finance, and since a widespread knowledge in finance is hardly commonplace, consumers should thus deserve some systemic protection. ${ }^{10}$

The needed skill to properly digest financial information, of course, transcends a mere ability to read and understand regular dictionary words that are used in everyday life. My personal experience regarding the consumption of financial services, corroborates Haim's findings that merely having a college degree is only a necessary but an insufficient condition in attaining financial literacy. ${ }^{11}$ In June 2012, a friend had secured an admission to a school in France, in which we agreed that I pay the acceptance fee of 200 Euro through my Euro bank account domiciled in Nigeria, on the arrangement of being reimbursed the equivalent in Naira currency. I processed the payment through my bank in

6 Chianu, E., 2007, The Horse and the Ass Yoked: Legal Principles to aid the Weak in a World of Unequals, $91^{\text {st }}$ Inaugural Lecture Series, University of Benin, p. 4, (http://www.nigerianlawguru.com/articles/jurisprudence/THE\%20HORSE\%20AND\%20ASS\%20YOKED,LEGAL\%20 PRINCIPLES\%20TO\%20AID\%20THE\%20WEAK\%20IN\%20A\%20WORLD\%20OF\%20 UNEQUALS.pdf, 20. 8. 2020).

7 Turgeon, E. N., 2008, Boom and Bust for Whom: The Economic Philosophy behind the 2008 Financial Crisis, Virginia Law \& Business Review, Vol. 4, No. 1, pp. 141-147.

8 Gang Z., Guangzi L., 2017, Consumer Finance and Its Significance, in: Wang G., Zeng G., Xiaoying X., (eds.) Development of Consumer Finance in East Asia, New York, Palgrave Macmillan, pp. 1-18.

9 Lusardi, A., Mitchell, O. S., 2014, The Economic Importance of Financial Literacy: Theory and Evidence, Journal of Economic Literature, Vol. 52, No. 1, 5-44, p. 6.

10 Emmons, W. R., 2005, Consumer-Finance Myths and Other Obstacles to Financial Literacy, Saint Louis University Public Law Review, Vol. 24, No. 2, pp. 335, 336-37.

11 Haim, L., 2013, Rethinking Consumer Protection Policy in Financial Market, Journal of Law and Commerce, Vol. 32, No. 1, pp. 29-30. 
Nigeria, and when I viewed my bank statement a few days later, I realized with surprise that about 265 Euro was deducted for this purpose. When I enquired, I was told that the extra 65 Euro was the sum charged by the corresponding bank in New York. I was surprised that the transaction I initiated with my bank in Nigeria had a connection with a New York bank for which 65 Euro was charged: this 'corresponding fee' was not disclosed to me in the outset when I made the transfer enquiries. If I were told in the beginning, I probably would have entertained the possibility of exploring other cheaper options of transferring the fee.

This story is a common experience among many financial consumers, whether with mainstream banks or other financial institutions in the context of home mortgages, credit cards, hire purchase, fund transfer, etc. And what makes it difficult in most cases is the inability to understand the numerous financial terminologies that appear on credit terms, and typically presented to these consumers on a standard form contract, on a take-it-or-leave-it basis. ${ }^{12}$ Following the 2008 financial crisis and the legislative reactions afterwards, there is hardly any scholarly disagreements these days that the framework underscoring consumer finance is complex and does not yet provide adequate protection for financial consumers.

\subsection{RESEARCH QUESTIONS \& METHODOLOGY}

In this paper, I try to answer the following questions, using existing qualitative and quantitative data. In addition, I use decided cases, provisions of law and anecdotal evidence to ascertain whether the current protection framework is generally insufficient for financial consumers. The reader is left to draw their final conclusion based on the analysis of facts and law. Similarly, even though bulk of the data analyzed as well as the authors of the sources relied on, emanate from the United States and European Union laws, it is argued that financial consumer protection law or issues are increasingly becoming uniform across the globe, and the analysis in this paper is meant to be a consciousness raiser especially for countries that newly embraced the market-based system and still experimenting with some of the underlying market principles. The questions that generally guide the discussions are:

i. What is the general plight of consumers in the financial marketplace, and how do the realities of market affect their lives?

ii. Why are the financial products by financial institutions typically complex for the consumers?

iii. What are the underlying costs of complex financial products for consumers?

iv. How do consumer regulatory bodies respond to issues of consumer exploitation, and are their policies and measures adequate protection?

12 See generally, Crawford, B., 2013, Financial-Consumer Complaint Agencies, Canadian Business Law Journal, Vol. 54, No. 1, pp. 68-86. 


\subsection{WHAT IS THE GENERAL PLIGHT OF CONSUMERS IN THE FINANCIAL MARKETPLACE, AND HOW DO THE REALTIES OF MARKET AFFECT THEIR LIVES?}

Gikay has observed that in relation to consumer financial contracts, a lot of complexities exist for consumers due to the knowledge imbalance between them and their financial institutions. ${ }^{13}$ Yet, given that financial prosperity is a strong pursuit in the $21^{\text {st }}$ century, most consumers cannot afford to stay away from financial undertakings: the various necessities of life such as owning salary accounts, taking up car loans or acquiring same on a hire purchase basis, buying from online retail stores, owning and operating borderless bank accounts, remote payment of household bills, are executed these days by consumers through deposit-based products and other mainstream methods of payment or through other emerging financial products. ${ }^{14}$ On a daily basis, it is realized that while a decade or two ago, it was possible to completely stay away from use of these financial products; nowadays, the exclusion of a consumer from mainstream financial products would negatively affect their social existence and wellbeing.

The high frequency with which financial products emerge these days makes it difficult even for college educated consumers to fully comprehend the inherent risks and benefits associated with the products on offer. As argued by Bar-Gill and Warren, when a consumer uses a financial product for which they lack sufficient understanding, the resulting consequences could be quite severe, and might end up threatening a consumer's sustainable wellbeing and sometimes, also those of their families, ${ }^{15}$ especially in those instances where as a result of improper comprehension of the credit terms, a consumer loses their mortgages, or get over-indebted from borrowing due to poor comprehension of what 'compound interest' actually means: in the last analysis, this affects their credit rating and future borrowing in the financial marketplace. ${ }^{16}$

Properly examined, it can be seen that the overall effect of consumers' improper understanding of complex financial products could impact negatively on their general confidence and trust in the financial industry, which of course,

13 Gikay, A. A., 2019, European Consumer Law and Blockchain Based Financial Services: A Functional Approach Against the Rhetoric of Regulatory Uncertainty, Tilburg Law Review, Vol. 24, p. 27, (http://doi.org/10.5334/tilr.135); Xavier, G., Laibson, D., 2006, Shrouded Attributes, Consumer Myopia, and Information Suppression in Competitive Markets, Quarterly Journal of Economics, Vol. 121, No. 2, pp. 505-540.

14 Haim, L., 2013, p. 28.

15 Bar-Gill, O., Warren, E., 2008, Making Credit Safer, University of Pennsylvania Law Review, Vol. 157, No. 1, p. 57, (https://www.law.upenn.edu/live/files/112-bargillwarren157upalrev12008pdf).

16 Anderson, K. B., 2016, Mass-Market Consumer Fraud: Who Is Most Susceptible to Becoming a Victim?, p. 23, (https://www.ftc.gov/system/files/documents/reports/mass-market-consumer-fraud-who-most-susceptible-becoming-victim/working_paper_332.pdf, 10. 9. 2020): it was observed that the "victims of investment and business opportunity frauds tended to be more educated than the population as a whole, while lottery fraud victims had lower levels of education". 
would have both market and social consequences. According to recent data, more than $30 \%$ of consumers did not anticipate from the outset, the exact fees they were later charged for the financial products they subscribed. ${ }^{17}$ In 2018, in reference to statistical data ${ }^{18}$ in the United States, it was incredibly realized that 99\% of consumer complaints filed to the country's Consumer Financial Protection Bureau (CFPB) were resolved after the relevant financial institutions provided explanations. ${ }^{19}$ This means that the consumers concluded the transactions notwithstanding their lack of the requisite information at the time of concluding the financial contracts.

Generally speaking, a sufficient understanding of any product is crucial towards avoiding their misuse and any appertaining consequences. In the context of consumer financial products, understanding the prices of products and the associated risks and burdens before making purchases is at the epicenter of consumer protection, because insufficient knowledge of the risks and terms of purchase, including whether there are exit options, weakens the ability to make informed decisions or undertake a responsible use of the products. Thus, even when a financial consumer eventually becomes aware of the full implications of the financial products they acquired, it could be realized that the transaction cost of switching to another product is high, including the possibility of suffering from losses due to early termination of contract, which was not properly disclosed by the financial institution in the outset. ${ }^{20}$

Inherent in any market system is the principle of laissez faire which profoundly dims the sight of consumers in their effort to make informed decisions, thus subjecting them to any underlying consequences as argued by Nilsson et al. ${ }^{21}$ This is further reinforced by the associated feature of laissez faire, i.e., the doctrine of caveat emptor, which holds purportedly that all consumers of adult age and sound mind have the freedom and power to conduct their independent searches towards discovering the best financial products in the market, and can thereafter choose their financial service providers, having carefully reviewed their terms and conditions which are written in the language the consumers understand. The caveat emptor focuses on the age and mental capacity of the consumer and hardly their knowledge of the product or the existence of any information-asymmetry that places them on a default disadvantageous position in respect of the product they are offered to buy. In truth, caveat emptor originated

17 The Harris Poll, 2019, Consumer Financial Literacy Survey, (https://www.nfcc.org/resources/ client-impact-and-research/2019-consumer-financial-literacy-survey/, 17. 7. 2020): "In general, many consumers expressed dissatisfaction of how their mortgage and other financial decisions turned out due to insufficient knowledge to make healthier financial choices."

18 See generally, Kraninger, K. L., 2018, Consumer Financial Protection Bureau. Consumer Response Annual Report, (https://files.consumerfinance.gov/f/documents/cfpb_consumer-response-annual-report_2018.pdf, 23. 7. 2020)

19 Ibid., pp. 17-25.

20 Klemperer, P., 1987, Markets with Consumer Switching Costs, The Quarterly Journal of Economics, Vol. 102, No. 2, pp. 376-378.

21 Nilsson, J., Nordvall, A. C., Isberg, S., The Information Search Process of Socially Responsible Investors, in: Harrison, T., (eds.), 2016, Financial Literacy and the Limits of Financial Decision-Making, London, Palgrave Macmillan, Cham, pp. 57-60. 
from commercial activities conducted in physical locations, thus only suitable for instances where the products under reference are physical goods which correspondingly offer potential buyers the opportunity to conduct physical examinations. ${ }^{22}$ This view is in tandem with Kiser's finding that based on statistical data, consumers rarely change their banks on the basis of their research-based findings of better services or prices by other competitor-banks mainly due to the intangible nature of the products. ${ }^{23}$

There is the prevailing assumption among financial consumers that all banks are one and the same: the transaction cost of switching from one bank to another may discourage consumers from harboring any interest or intention to switch to other banks: even though one would have thought that given the crucial nature of financial products in the lives of consumers, they would devote much time and resources in discovering best available products and services in the market. Yet as such investigations require expertise and financial resources to undertake, consumers typically surrender the task in the hands of regulators of banking and financial institutions who paradoxically, do not see things differently from those they purport to regulate. The question then is why and how did it get to the position whereby one of the most important economic sectors for consumers is allowed to develop and sell complex financial products and services which on aggregate are unhealthy both for the consumers and the economy?

\section{WHY ARE THE FINANCIAL PRODUCTS BY FINANCIAL INSTITUTIONS TYPICALLY COMPLEX FOR THE CONSUMERS?}

\subsection{THE FIRST DIAGNOSED REASON: THE CAVEAT EMPTOR RULE REQUIRES CONSUMERS TO PULL THEMSELVES UP BY THEIR OWN BOOTSTRAPS}

The average expectation, is perhaps, to have a system whereby consumer financial products are simplified as much as it is possible, considering the heightened importance of comprehension of the risks and benefits associated with these products. Yet in today's financial systems, what is commonplace is the existence of a myriad complex products: a few reasons could be responsible for this situation. The first reason is that financial institutions in a market economy are primarily in existence to make profits, and more profits for their shareholders on the basis of the shareholder primacy doctrine. ${ }^{24}$ The appetite for profit

22 See Bradgate, R., 2000, Commercial Law, London, Butterworths, p. 273.

23 See the detailed survey conducted by Professor Kiser on the switching of banks behavior of households. Kiser, E. K., 2002, Household Switching Behavior at Depository Institutions: Evidence from Survey Data 8, Federal Reserve Board, Financial \& Economic Discussion Series, Working Paper No. 44, pp. 2-5, (https://www.federalreserve.gov/pubs/feds/2002/200244/ 200244pap.pdf, 9. 8. 2020).

24 Velasco, J., 2010, Shareholder ownership and primacy, University of Illinois Law Review, 897 at 944, (https://scholarship.law.nd.edu/cgi/viewcontent.cgi?article=1331\&context=law_faculty_scholarship). 
is to a large extent motivated by short term behavior, and this arrangement is inconsistent with the wellbeing of a financial consumer. In this regard, a typical practice among financial institutions is to present terms of financial contracts in an enticing manner, showcasing only the benefits but hardly the risks and side effects associated with the financial products. ${ }^{25}$ Being that such deceptive set of practices are often industry-wide, there is hardly any incentive for a financial institution to engage in altruistic behavior of presenting both risks and benefits with equal force, as they fear loss of patronage; consumers are not usually trained to effectively digest financial risks: they mostly prefer to patronize product sellers who do not emphasize on any underlying risks. Therefore, financial institutions have over a long period of time learned to solely communicate the beneficial aspects of the products they sell to their consumers, and allow them to discover the hidden costs and onerous terms at their own expense, usually after they had been exploited for some time. ${ }^{26}$

The work of Gabaix and Laibson captures the forgoing discourse: it reveals the inability of most consumers to properly choose financial products based on price and benefits consideration due to the effect of 'shrouding': a situation whereby financial institutions influence upfront the consumption behavior of their consumers by aggressively marketing the appealing sides of products and shrouding or masking the unappealing sides of them such as the backend fees, penalties, surcharges, etc. ${ }^{27}$ Based on my personal experience, for example, banks do prepare standard form contracts and present same to potential customers that are desirous of opening bank accounts. Often times, a customer is only shown places in the contract document to append their signatures without any opportunity to read and understand the terms and conditions: the fact that this practice is obtainable largely in the banking industry discourages a customer from raising any objections, or refusing to open a bank account on grounds of unfavorable terms of contract. ${ }^{28}$

25 Ellison, G., 2005, A Model of Add-On Pricing, Quarterly Journal of Economics, Vol. 120, No. 2, pp. 585-637; DellaVigna, S., Malmendier, U., 2004, Contract Design and Self-Control: Theory and Evidence, Quarterly Journal of Economics, Vol. 119, No. 2, p. 353.

26 Jager, C. E. de, 2017, A Question of Trust: the Pursuit of Consumer Trust in the Financial Sector by Means of EU Legislation, Journal of Consumer Policy, Vol. 40, No. 3, pp. 25-49, 40. Jager explained that "[ $\mathrm{t}]$ he drafting, sending, and interpreting of questionnaires costs time and money, meaning that there are incentives for banks to keep them short and to let investors categorize themselves."

27 Gabaix, X., Laibson, D., 2006, Shrouded Attributes, Consumer Myopia, and Information Suppression in Competitive Markets, Quarterly Journal of Economics, Vol. 121, No. 2, pp. 505-507.

28 Ko, K. J., Williams, J., 2013, The Effects of Regulating Penalty Fees for Consumer Financial Products, Sec. \& Exch. Comm'n Div. of Risk, Strategy \& Fin. Innovation, Working Paper No. 3, p. 2, (http://papers.ssrn.com/sol3/papers.cfm?abstract_id=2122793, 10. 8. 2020): "a number of studies find that a large proportion of consumers, in fact, do not understand key lending terms and underestimate future costs. Such obscured costs can cause certain consumers to unknowingly enter into transactions that are ultimately welfare-reducing. For example, a college student may choose a debit card as his method of payment because it is more convenient than cash. He may then regret this decision once he learns about the penalty fees that are eventually imposed. In addition, markets with hidden add-on costs can allow for implicit transfers between consumers who use the product differently .... 
In many cases, I have viewed my bank statements and seen many monthly charges termed as 'ATM withdrawal charges', 'account maintenance fee', 'debit card maintenance fee', etc., and many of these charges were not disclosed to me at the time of opening the bank account. In effect, shrouded financial products are parts and parcel of a free or less regulated market system: due to the caveat emptor rule, consumers ought to have made their independent enquiries before purchasing products: the rule does not put a sufficient obligation on the seller to actively point out defects. Thus, the caveat emptor rule coupled with a free market system creates an overwhelming appetite for financial institutions to sell complex/shrouded products to their consumers.

\subsection{THE SECOND DIAGNOSED REASON: MOST CONSUMERS DO NOT ALWAYS FOCUS ON THE LONG TERM EFFECTS OF THEIR FINANCIAL DECISIONS}

A typical financial consumer does not always focus on long term effects of their decisions when choosing financial products. ${ }^{29}$ As O'Donoghue and Rabin argued, financial consumers are enticed mainly by the relative ease of initial costs, and on average, can easily choose a product that its initial requirements, costs, and benefits are relatively simpler, cheaper and better compared to another substitute with opposite features but better in the long run. ${ }^{30}$ Moreover, owing to the feeble freedom to quit use of a product at any time, i.e., the opportunity to switch to a comparable product offered by another financial institution in the future, the probability of focusing on long term issues regarding a chosen product becomes consequently low. Since the forgoing appears to be the default position of a typical financial consumer, most financial institutions have modelled their products to exactly reflect this consumer behavior: they design and offer products that are competitively enticing to consumers in the short term to enable them begin use of the product without much hesitation. Using a product invariably produces an endowment effect on the consumer or a situation where as a result of becoming familiarized with the product, they find it reluctant to switch to another product which might require them to expend time and resources in learning to use. ${ }^{31}$

Most financial institutions are designed to exist in perpetuity and can therefore afford a long term patience: in the long run period of a consumer's product use, and per contract, most of the hidden charges and unfavorable terms begin to kick into effect, and a busy consumer will find it difficult to quit or would simply assume that all financial institutions are offering the same products on similar terms, especially if there is no easy access to regulators or consumer pro-

29 Howcroft, B., Hewer, P., Hamilton, R., 2003, Consumer Decision-Making Styles and the Purchase of Financial Services, The Service Industries Journal, Vol. 23, No. 3, pp. 63-81.

30 O'Donoghue, T., Rabin, M., 1999, Doing It Now or Later, American Economic Review, Vol. 89, No. 1, pp. 103-04.

31 Kumar, A., Gilovich, T., 2016, To Do or to Have, Now or Later? The Preferred Consumption Profiles of Material and Experiential Purchases, Journal of Consumer Psychology, Vol. 26, No. 2, pp. 169-178. 
tection bureaus to effectively resolve complaints. Thus, the low initial costs of products in the short term precisely dim the sight of consumers in locating the hidden and unfavorable terms that operate in the long run in respect of a chosen product: this is one of the reasons most financial products, even though complex to fully understand, are still patronized by consumers who appear to be enticed with an offer that guarantees enjoyment of the low hanging fruits in the short term, with a coupled promise to quit in the long term in the event they find it unfavorable. $^{32}$

\subsection{THE THIRD DIAGNOSED REASON: THE BUNDLING OF FINANCIAL PRODUCTS BY FINANCIAL INSTITUTIONS}

As Bar-Gill noted, the prevalent wisdom in the financial service industry is to bundle a group of services together and name them as one product. ${ }^{33}$ In a way, the competitiveness of a financial product is measured by the number of services that are presented as one product: Nalebuff noted that it is a marketing strategy that is typically exploited by the marketing departments of financial institutions. ${ }^{34}$ Because they are a group of services presented as one, the consumer is not knowledgeable or sophisticated enough to assess the quality of delivery in respect of each of those services: in fact, some of the included services will not be useful to the consumer. From a personal experience in 2018, I was offered a financial product by my bank's marketer in Nigeria, which according to them was a product they offered to their very special customers who on aggregate had deposited a substantial amount of money in the last five years. This financial product called "Xclusive Plus" offered by Access Bank Plc, was designed to acknowledge and treat me as an important bank customer, and conferred me the benefit of having my bank related requests treated on a priority basis any time I had any reason to call or physically visit the bank. Other services tied to this product were: a monthly availability of a movie ticket at a cinema that was actually located far away from the residential address I provided the bank; a monthly body massage at a designated center that was also far away from my residence; and use of the bank's lounge in certain airports in the event my flight was delayed. ${ }^{35}$

In exchange for these services which were hardly utilized, about six thousand naira (approximately US\$25) was deducted from my account each month; this fee was far more than the enticing sum that was orally disclosed to me in the beginning. I was unhappy at the price and had to quit using the "Xclusive Plus" product. Therefore, one of the reasons financial products are typically complex

32 Meier, S., Sprenger, C., 2010, Present-Biased Preferences and Credit Card Borrowing, American Economic Journal: Applied Economics, Vol. 2, No. 1, pp. 193-194: "Present bias is argued to increase individuals' desire for instant gratification and, as a result, increase borrowing".

33 Bar-Gill, O., 2006, Bundling and Consumers Misperception, University of Chicago Law Review, Vol. 73, No. 1, pp. 38-51.

34 Nalebuff, B., 2003, Bundling, Tying, and Portfolio Effects, DTI Economics Paper, No. 1, pp. 13-27, (https://www.immagic.com/eLibrary/ARCHIVES/GENERAL/UK_DTI/T030207D. pdf, 8. 8. 2020).

35 Xclusive Plus, (https://www.accessbankplc.com/XclusivePlus, 23. 7. 2020). 
for consumers to understand, is because, financial institutions do regularly tie many services to a product in order to justify their high charges, even when they are aware of the low probability of the consumer's use of all the bundled services, or having enough interest and resources to evaluate and sue or report an unsatisfactory delivery of the services to regulators; as already indicated by earlier studies, a consumer's ability to understand bundled products decreases sharply if the number of bundled products exceeds three. ${ }^{36}$

\subsection{THE FOURTH DIAGNOSED REASON: CONSUMER'S DIFFICULTY IN COMPREHENDING FINANCIAL TERMINOLOGIES}

Financial terminologies are typically complex and comprise of terms from disciplines such as law, accounting, banking and finance, information technology, etc. Financial institutions are able to synthesize all of these concepts and terminologies in the descriptions of financial products, chiefly because they have the relevant manpower to do so. Nearly always, the contracts on the basis of which financial products are prepared and offered to consumers, embody these complex terminologies that require some formal knowledge of the aforementioned disciplines. Yet these knowledge abilities are far from being at the disposal of an average consumer, and while an option may be to purchase professional advisory services, the reality is that this is not generally the case due to the high cost of acquiring the relevant professional services compared to any possible financial losses of the consumer in the short term in respect of a given product.

Shortly after the 2008 financial crisis, Lacko and Pappalardo conducted qualitative experiments which validate the forgoing concerns. They found that most financial consumers were not able to understand the basic terms such as 'amount financed', 'discount fee', 'back-end fee', etc., and without seeking a professional interpretation of the terms, the lack of proper understanding could thus lead a consumer to take financial decisions that are not only expensive but also destructive to their long term financial standing. ${ }^{37}$

In effect, the use of complicated financial terminologies which may have meanings different from what common sense or an ordinary language dictionary can provide, makes financial products very complex for consumers. ${ }^{38}$ Yet from a market standpoint and shareholder primacy rule, profit is much more desirable for financial institutions than any altruistic actions that will benefit consumers at the expense of profits. Looking at the way financial market systems are designed, coupled with the doctrine of freedom of contract, there is little or no incentive

36 Schwartz, A., Grether, D. M., Wilde, L. L., 1986, Irrelevance of Information Overload: An Analysis of Search and Disclosure, Southern Californian Law Review, Vol. 59, pp. 296-297, (https://digitalcommons.law.yale.edu/cgi/viewcontent.cgi?article=2099\&context=fss_papers).

37 Lacko, J. M., Pappalardo, J. K., 2010, The Failure and Promise of Mandated Consumer Mortgage Disclosures: Evidence from Qualitative Interviews and a Controlled Experiment with Mortgage Borrowers, American Economic Review, Vol. 100, pp. 518-19, (https://pdfs.semanticscholar.org/352a/736e64ce16aa0ee97be0eb2e0d1fc3acc48d.pdf, 10. 7. 2020).

Ibid., p. 517. 
for financial institutions to engage in activities that will reduce complexities around the products they offer since they benefit enormously from deception. In any event, a simple diagnosis in this regard shows that product complexities hurt the financial wellbeing of consumers, which could on aggregate, lead to an economic crisis due to the ensuing reduction of consumer trust in the financial industry, and a concomitant tear at the fabric of society and economic wellbeing.

\section{WHAT ARE THE UNDERLYING COSTS OF COMPLEX FINANCIAL PRODUCTS FOR CONSUMERS?}

\subsection{WHAT IS THE GENERAL TRANSACTION COST?}

Every market economy is generally ruled by the desire to make profits through efficiency in production. If the cost of obtaining information regarding a particular financial product is higher than the benefits attributed to them by the consumer, then from the perspective of profit maximization, the opportunity cost of obtaining the information would be preferred. However, while a simple economic calculation of opportunity cost could be generally undertaken for products other than those of finance, in the latter (due to the high necessity of finance in the life of a consumer), the cost of finding information and analyzing them in order to make healthy financial decisions might require the consumer to pursue it at all cost: yet irrespective of the importance, this is hardly the case. The outrageous costs of acquiring and processing information could make consumers to give up a search towards understanding financial products being offered to them, and as a result, they could easily capitulate to the consequences attached to using complex and incomprehensible financial products.

\subsection{WHAT IS THE COST OF DIGESTING A LARGE QUANTUM OF INFORMATION?}

As earlier indicated, information and knowledge are crucial tools in unlocking the complexities of financial products, and many financial institutions and regulatory bodies do provide information which they unilaterally believe will sufficiently assist consumers in understanding the complexities of any financial products they purchase and consume. Even though financial institutions provide information either as a result of corporate practice or mandatory rules of disclosure, the excessive quantum of information provided over a single product: information that runs in tens of pages, could discourage a consumer towards having a thorough examination of the terms and conditions of the product or the underlying risks. ${ }^{39}$ Similarly, some consumers are not able to sufficiently understand the complex language used by financial institutions to describe products, neither do they possess the ability to analyze numerical data, which truly

39 Iyengar, S. S., Lepper, M. R., 2000, When Choice is Demotivating: Can One Desire Too Much of a Good Thing?, Journal of Personality \& Social Psychology, Vol. 79, p. 995 (discussing the effects of information overload on consumers which whittles their ability to make real choices). 
require some degree of expertise in finance to comprehend: examples are financial terms such as 'compound interest', 'double cycle billing' 'back-end fee', etc. ${ }^{40}$ Thus, the lumping of all financial consumers into one basket and treating them as equal and sophisticated is premised on the faulty assumption that they will be able to properly understand and make informed financial decisions on the basis of their age and mental capacities.

The complexity of financial products is best understood if one briefly considers that even with sufficient literacy and numeracy skills, full comprehension of product risks could still be an insurmountable challenge. For example, in the context of dispute settlement whereby judges are called upon to examine the contents of financial products under dispute, the learned judges still struggle to understand the terminologies and the underlying complexities. For instance, in 1956, in J. Spurling Ltd v. Bradshaw, ${ }^{41}$ the English judges lamented over the obscurity of the contractual terms of the financial products: resting on the doctrine of contra proferentem, they directed that the party (the financial institution) who drafted the contract had the responsibility to simplify the ambiguous terms, i.e., caveat venditor.

Typical disputes on financial products take a significant amount of time for courts to resolve, and sometimes, expert opinions are sought by judges to aid comprehension and interpretation in order to enable them make authoritative comments regarding the financial products under reference. The rhetorical question that ensues is: if it takes expert tribunals a significant amount of time to digest issues regarding complex financial products, then for a consumer faced with many barriers such as insufficient levels of literacy and numerical knowledge, limited time and financial resources, isn't the expectation on them to fully comprehend complex financial products and make informed decisions is profoundly unrealistic and unfair? ${ }^{42}$

\subsection{HIGH SEARCHING AND SWITCHING COSTS PROMOTE THE EXISTENCE OF PRODUCT COMPLEXITIES}

In a market system, it is assumed that rational consumers will be motivated to search and locatefinancial products that are price-competitive so as to maximize their limited income resources. This price-based competition optimizes the economy:

40 Lusardi, A., Mitchell, O. S., 2007, Financial Literacy and Retirement Preparedness: Evidence and Implications for Financial Education Programs, Business Economics, p. 36 (https://www. dartmouth.edu/ alusardi/Papers/Financial_Literacy.pdf, 8. 8. 2020): The authors conducted a survey, in which "[T] he surveys consisted of a 24-item questionnaire on topics grouped into categories including 'Economics and the Consumer'; 'Money, Interest Rates and Inflation'; and 'Personal Finance'. When results were tallied using standard grading criterion, adults had an average score of ' $\mathrm{C}$ ', while the high school population fared even worse, with most earning an $\mathrm{F}$ (average score of 53\%). Particularly troublesome were the sections dealing with money, interest rates, inflation, government and trade, and personal finance. The report also indicated gender and minority gaps: White students and adults tended to score higher than their Black and Hispanic peers, and women scored lower than men."

41 See J. Spurling Ltd. v. Bradshaw [1956] 1 WLR 461, 466.

42 Campbell, J. Y. et al., 2010, The Regulation of Consumer Financial Products: An Introductory Essay with Four Case Studies, Faculty Research Working Paper Series, pp. 9-15, (https:// research.hks.harvard.edu/publications/getFile.aspx? Id=602, 9. 8. 2020). 
financial institutions will strive to be efficient in providing products that are competitive in all respects. ${ }^{43}$ However, this economic situation is premised on the assumption that financial consumers are not inhibited by the barriers that disable them from understanding the complexities surrounding financial products, and are carrying out searches for better products with the requisite knowledge. The high cost of engaging in constant search in order to locate comparably lower costs of financial products, boils down to discouraging many consumers from attempting to do so in the first place. As Kiser noted, about $32 \%$ of households in the United States have never changed their banks, and a significant percent of those who did change their banks, did so because of reasons other than mere dissatisfaction of the products being offered to them by their banks. ${ }^{44}$ The major reason for this apathy towards searching for better financial products across banks and other financial institutions is the fact that search cost usually outweighs the short term losses that most consumers experience, and this consequently whittles their appetite to switch to comparable products. ${ }^{45}$

Lastly, in the relationship of financial institutions and their consumers, it can reasonably be asserted that the latter largely bear the costs of transaction: whatever costs that are incurred in the process of producing the complex products are factored into the retail prices of the products that are sold to the consumers. In other words, there is a high incentive for financial institutions to engage in the production of complex products given that on one hand, the complexities disable consumers from fully understanding all the risks associated with a given product, and thus increase their propensity to purchase them. Yet, on the other hand, the cost incurred in producing the products, the booklets containing information as necessitated by industry practice or as mandated by financial regulators, the cost of training employees of the financial institutions towards understanding the products, and the costs of distribution of the information are secretly transferred to the consumers through product prices. ${ }^{46}$

\section{HOW DO CONSUMER REGULATORY BODIES RESPOND TO ISSUES OF CONSUMER EXPLOITATION; ARE THESE POLICIES AND MEASURES ADEQUATE PROTECTION?}

The discussion so far has sought to establish that financial institutions in a market system are motivated by profits to produce complex financial products for consumers: judging from the average consumer's point of view, the insufficient level of required literacy and numerical skills, the general discomfort and costs associated with analyzing, comparing and switching to comparably better

43 Ibid., p. 7.

44 Kiser, E. K., 2002, pp. 6-7, 19.

45 Ibid., p. 10.

46 Melecky, M., Rutledge, S., 2016, Financial Consumer Protection and the Global Financial Crisis, MPRA Paper No. 28201, p. 2, (https://mpra.ub.uni-muenchen.de/28201/1/MPRA_paper_28201.pdf, 10.9. 2020). 
products in the market (which are too high for individual consumers to undertake), constitute barriers that are taken advantage of by financial institutions. What all this reveals, is the vulnerability of financial consumers and the exploitation of this vulnerability by financial institutions who are incentivized by these barriers, and whose profits largely depend on deception through presentations of shrouded and complex products. The policy question therefore is what is generally the legal framework for protecting financial consumers and to what extent is such framework sufficiently protective of financial consumers? ${ }^{47}$ Below, I argue that the main protections or legislative responses found in most consumer protection frameworks are insufficient.

\subsection{THE FIRST TYPE OF RESPONSE: MANDATORY RULES OF DISCLOSURE}

Economics celebrates the rational consumer: there is the presumption that consumers will make informed and better financial decisions if the full benefits and burdens associated with the financial products offered to them are disclosed at the offer stage and afterwards as mandatorily required. Disclosure is considered to be an effective antidote against deceptive practices that encourage the development and sale of shrouded financial products, even though it could be agreed that not all consumers are rational and should not be left unprotected in the hands of financial institutions. While on a prima facie consideration, it could be said that financial consumers benefit from disclosure, what is paradoxical about disclosure is its uncanny ability to swell up the quantum of information for a consumer's digestion, and thus discourage information consumption as elaborately noted by Ben-Shahar and Schneider. ${ }^{48}$ Invariably, this can reinforce strength of the barriers that make it difficult for consumers to understand complex financial products.

Disclosure, whether as required in the Dodd Frank Act, ${ }^{49}$ Truth and Lending Act, ${ }^{50}$ Real Estate Settlement Procedures Act, or any other comparable legislation, ${ }^{51}$ is based largely on the presumption that all or substantially all consumers

47 See for instance the reassurance of the Federal Trade Commission titled 'Consumer Finance', (https://www.ftc.gov/news-events/media-resources/consumer-finance, 8. 8. 2020).

48 Ben-Shahar, O., Schneider, C. E., 2011, The Failure of Mandated Disclosure, University of Pennsylvania Law Review, Vol. 159, pp. 705-709, (https://www.law.upenn.edu/journals/ lawreview/articles/volume159/issue3/BenShaharSchneider159U.Pa.L.Rev.647(2011).pdf, 10. 6. 2020).

49 See Title X of the Dodd-Frank Wall Street Reform and Consumer Protection Act, which among other things, established the Consumer Financial Protection Bureau.

50 See generally, the protection of financial consumers in "Truth in Lending Act - Consumer Rights and Protections", stating that "Lenders must provide a Truth in Lending (TIL) disclosure statement that includes information about the amount of your loan, the annual percentage rate (APR), finance charges (including application fees, late charges, prepayment penalties), a payment schedule and the total repayment amount over the lifetime of the loan", (https://www.debt.org/credit/your-consumer-rights/truth-lending-act/, 30. 6. 2020).

51 Other pieces of notable legislation in this regard are the Home Owners Protection Act, the Home Mortgage Disclosure Act, and the Secure and Fair Enforcement for Mortgage Licensing 
of financial products do have the requisite ability and resources to understand the complex financial information that is provided to them in the official language of the country where they reside. Irrefutably, for an information disclosure to be truly effective, the idiosyncratic conditions of each consumer ought to be taken into consideration instead of treating all consumers alike. Critics however argue that this approach will add to the cost of disclosure on the part of financial institutions, and the vast sums will eventually be transferred to product prices which consumers buy. In any event, the presumption of sufficient knowledge by consumers to properly analyze disclosed information, is factually inaccurate: a substantial number of consumers in the financial marketplace are not able to process the sophisticated pieces of information which are characterized with financial terminologies and presented in a manner that requires some high degree of financial skills to understand.

The ultimate question then is: to what extent does disclosure benefit financial consumers? First, disclosure will be counterproductive if consumers are flooded with a myriad information regarding a particular product. As Ben-Shahar and Schneider opined, when some of the provided pieces of information do not bear direct relevance to the product but are in a way miscellaneous and unrelated figures on a variety of products offered by the financial institution, then the chances of filtering and locating what information is useful become unsurprisingly slim. ${ }^{52}$ Second, as financial institutions are driven largely by profit maximization, their default position is not to comply with the mandatory rules of disclosure in a way that benefits the consumers: instead they find a way to fulfil minimum statutory requirements while in effect bypassing the ultimate goal. So in that case, financial institutions that constantly invest in product innovations will always be ahead of regulators and courts: they can afford to study and understand voluminous materials or legislation embodying the mandatory rules and accordingly restructure their pricing techniques in a way that legally bypass the rules. ${ }^{53}$

Concluding on this point, it can be said that disclosure rules can only be effective if regulators ensure that the type of information sent to consumers is simple enough to capture the essential points, easily digestible and not calculated to frustrate the consumers' interest to read the provided information. In that regard, apart from the need to provide disclosure information in small doses, the amount of words, the font size, the graphs, statistical tables, etc., have to be controlled in a way that fulfils the ultimate purpose of disclosure, which is to assist financial consumers to make informed and healthier financial decisions. Disclosure is undoubtedly an ex-ante remedy: they mitigate the quantum of financial losses that a consumer will likely incur if they were not to be furnished with adequate and relevant information in relation to the financial products they

Act, the Electronic Funds Transfer Act, the Credit Repair Organization Act, and the Truth in Savings Act, the Fair Credit Reporting Act, the Fair Debt Collection Practices Act, etc.

52 Ben-Shahar, O., Schneider, C. E., 2011, pp. 710-723.

53 Bar-Gill, O., 2012, Seduction by Contract: Law, Economics, and Psychology in Consumer Markets, London, Oxford University Press, p. 85. 
consume, and in evaluating whether a financial institution's disclosure is satisfactory, the ex-ante remedial notion should be borne in mind.

\subsection{THE SECOND TYPE OF RESPONSE: INCREASING CONSUMER FINANCIAL EDUCATION AND LITERACY}

Another ex-ante remedy that protects financial consumers is education aimed precisely at increasing financial literacy in respect of complex financial products, and financial decisions-making in general. There is a social benefit that accrues when financial consumers are properly educated in relation to the products they consume: they get to better appreciate the risks inherent in their decisions of what to consume, the need to assess credit offers from the short and long term lenses; the need to understand the meaning and types of interest rates, double cycle billing, back-end fee, corresponding fee, etc. ${ }^{54}$ Consumer education can be much more effective when the contents are designed to match the interest and understanding of the various demographics in society. ${ }^{55}$ Stanescu has argued that even the European Union that is often praised for being very protective of their consumers, ${ }^{56}$ nowadays in respect of financial consumers, seems to be similar to what is obtainable in the U.S. where the laissez faire system is alive and well. He further observed that "consumers are now expected to help themselves by pursuing financial education, raising their knowledge and awareness levels, seeking advice, keeping updated with technological or financial innovations and making rational decisions, even though the complexity of the products and services offered is only increasing. This position of the EU policy makers and judiciary raises the question whether consumer protection did not turn into a self-help mechanism for most of the consumers, from vulnerable groups upwards." 57

However, like most ex-ante remedies, critics maintain that the true impact of consumer education can be difficult to measure: it is preventive and there is no way to concretely know in retrospect the number of consumers that would

54 To further understand financial consumer literacy and how it affects their choices of financial products, see Cole, S., Shastry, G. K., 2008, If You Are So Smart, Why Aren't You Rich? The Effects of Education, Financial Literacy and Cognitive Ability on Financial Market Participation, Working Paper 09-071 Harvard Business School, pp. 6-15, (https://www.econbiz. de/Record/if-you-are-so-smart-why-aren-t-you-rich-the-effects-of-education-financial-literacy-and-cognitive-ability-on-financial-market-participation-cole-shawn/10003788911, 10. 8. 2020).

55 Financial Literacy and Education Commission, 2016, Promoting Financial Success in the United States: National Strategy for Financial Literacy, p. 7, (https://www.treasury.gov/resource-center/financial-education/Documents/National\%20Strategy\%20for\%20Financial\%20Literacy\%202016\%20Update.pdf, 20. 7. 2020)

56 E.g., see Art. 169, Treaty of the Functioning of the European Union; Art. 38 Charter of Fundamental Rights of the European Union.

57 Stănescu, C. G., 2019, The Responsible Consumer in the Digital Age: On the Conceptual Shift from 'average' to 'responsible' Consumer and the Inadequacy of the 'information Paradigm' in Consumer Financial Protection, Tilburg Law Review, Vol. 24, No. 1, p. 50, (https:// tilburglawreview.com/articles/10.5334/tilr.143/, 10. 7. 2020). 
have suffered financial losses as a result of consuming complex products, but averted same due to the benefits of consumer education. ${ }^{58}$ In that case, and in the long run, it can be difficult for advocates of consumer education to justify the resources channeled towards such educational programs and campaigns, and this could possibly lead to a reduction of the financial resources mapped out for consumer education. Yet, sustainability of consumer educational programs is crucial because given the constant innovation of financial products, a knowledge imparted on a consumer today, will likely become obsolete after a short period of time. ${ }^{59}$ It is to be praised for instance, that the Dodd Frank Act statutorily incorporated the education of consumers as a long term viable solution towards preventing the occurrence of financial crises. ${ }^{60}$ The "Ask CFPB," ${ }^{1}$ is a viable online platform that has provided several answers to frequently asked questions by consumers, and this is a good example of sustainable consumer education, which I generally advocate in this paper.

\subsection{HOW SHOULD THE GAPS IN THE EXTANT NATURE OF RESPONSES BE CLOSED?}

\subsubsection{Prevention of 'Regulatory Capturing' by financial institutions}

Financial institutions are undoubtedly powerful and possess sufficient resources to favorably influence the outcomes of any policies that affect them. Consumers are regular citizens and usually repose their trust and confidence in public institutions (regulators/courts) for their protection. The high level of trust reposed in regulatory institutions can make consumers a bit laid back in self-equipment of financial knowledge: they tend to largely believe that those whom they pay with their tax resources are awake and looking after them. As policy or lawmakers are usually elected into offices, their elections and the underlying campaigns cost vast sums of money. ${ }^{62}$ The needed financial resources may not be personally available to the contesting politicians at the time of elections: they heavily rely on donations from members of the public to fund their election campaigns. Even though it is not often admitted, it can be reasonably said that politicians who directly or indirectly receive huge financial donations from financial institutions to fund their election campaigns cannot sincerely be expected to make stringent laws or policies against those institutions toward

58 Willis, L. E., 2009, Against Financial Literacy Education, Iowa Law Review, pp. 202-04, 260 275; Mann, R. J., 2012, After the Great Recession: Regulating Financial Services for Low- and Middle-Income Communities, Washington \& Lee Law Review, Vol. 69, 729, p. 740, (https:// scholarlycommons.law.wlu.edu/wlulr/vol69/iss2/8/).

59 Haim, L., 2013, p. 54.

60 See Dodd-Frank Wall Street Reform and Consumer Protection Act, 111 Pub. L. No. 203, Section 1205(b)(2).

61 See Ask CFPB, Consumer Financial Protection Bureau, (https://www.consumerfinance.gov/ ask-cfpb/).

62 Hempling, S., 2013, Regulatory Capture: Sources and Solutions, Emory Corporate Governance and Accountability Review, (https://law.emory.edu/ecgar/content/volume-1/issue-1/essays/ regulatory-capture.html, 10. 10. 2020). 
curbing their exploitation of financial consumers. In that case, the one who pays the piper could afford to dictate the tunes. ${ }^{63}$

The current protective remedies offered by regulators, generally make it seem that only the consumers need to be educated or have their capacities reinforced so as to understand the complexities of the financial products offered to them, and consequently avoid losses. This approach epitomizes victim-blaming, offering a pictorial depiction of chasing a wild goose. Even if it were to be assumed that consumers understand the complexities surrounding financial products, the knowledge would not produce much beneficial outcome if all other financial institutions are offering products of comparable complexities, thus making it difficult or impossible for the consumers to have a real choice. Therefore, consumer education and mandatory rules of disclosure as they are currently provided in many consumer legislations around the globe, seriously miss the main point: financial institutions are ideally created to live in perpetuity, thus could invest enormously toward protecting their source of income in the long run: they could always bypass the rules by designing products that will be outside the regulatory ambit, thus requiring regulators (often poorly funded) to constantly chase after them.

Currently, also, financial institutions are regulated by their central/national/ reserve banks, and this is almost equivalent to being a judge in one's own case, since the regulators are trained in the same financial industry and can hardly have a perspective that is materially different from the practices of the commercial banks they regulate, who are purely motivated by profits. Consumer bureaus such as the CFPB or their equivalents, are admittedly recent creatures and can only afford to play a catch up game with respect to financial innovations and the ensuing products and services: or as Tajti aptly puts it: "[s]ome protection is available to consumer-creditors in every system; the issue is that they are often inadequate." ${ }^{\prime 4}$

\subsubsection{Financial institutions are not sufficiently bearing the costs of complex products: the need to require delivery of education against self-interest}

Rather than require consumer bureaus to take up the job of ascertaining what amounts to complex products or the extent to which it can be acceptable in the financial marketplace, financial institutions should be made to bear the

63 Mathilde, P., Regulatory Capture in Financial Supervision, in: Douady, R., Goulet, C., Pradier, P. C. (eds.), 2017, Financial Regulation in the EU, Palgrave Macmillan, Cham, pp. 108-112. As Mathilde explained, "regulatory capture occurs when an industry has an excessive influence over the regulatory or supervisory processes. In the wake of the financial crisis of 2007-08, officials and academics could only observe that the prudential oversight of the financial industry has failed. This failure was soon attributed to regulatory capture and brought academics and officials to consider other channels of influence than traditional lobbying or corruption.” Also see Albino, D., Hu, A., Bar-Yam, Y., 2013, Corporations and Regulators, the Game of Influence in Regulatory Capture, Working Paper, pp. 5-7, (https://arxiv.org/pdf/1310.0057.pdf, 10. 7. 2020).

64 Tajti, T., 2019, Unprotected Consumers in the Digital Age: The Consumer-creditors of Bankrupt, Abandoned, Defunct and of Zombie Companies, Tilburg Law Review, Vol. 24, No. 1, p. 5, (http://doi.org/10.5334/tilr.139). 
burden of ensuring that the consumers whom they offer their products have sufficient understanding of the offered products; in other words, an application of the caveat venditor rule. ${ }^{65}$ If one starts from the premise that financial institutions ought to act in good faith, and at any rate, are in the best position to perfectly understand the risks and benefits associated with the products they offer, then they should bear the burden of ensuring that the consumer literacy level required to understand the complexities surrounding their products is imparted and achieved. In that case, the consumer regulatory bodies and courts can take the supervisory role of ensuring compliance of this ultimate goal. Regulators could start by requiring financial institutions to use same level of language to write in a tabular format, equal number of disadvantages and risks alongside the benefits of a given product in the information booklets they provide to consumers.

The role of financial consumer regulators, policy makers and courts will then be to use the doctrine of purpose to assess whether financial institutions adhered to the true measure of disclosure of information against self-interest: providing information against self-interest will inform consumers on the full extent of product risks. To repeat, such information should be comprehensible and in clear formats, presented as equal number of risks or disadvantages of a product vis-à-vis equal number of the underlying benefits. ${ }^{66}$ In the last analysis, especially in the aftermath of the Covid-19 pandemic, this approach will likely increase transparency in the financial marketplace; ${ }^{67}$ increase consumer trust and confidence in the system which is much needed by depository banks to thrive as well as acquire a consumer wellbeing culture in the long run: all this will likely lower the cost of supervision and enforcement on the part of regulators and courts. ${ }^{68}$

The requirement to provide a consumer education that is against the self and narrow interests of financial institutions might lead to increment in the cost of financial products as these institutions might calculate and push the costs into their product prices. However, increasing consumer trust by ensuring more transparent processes in the financial products being sold to them will in my opinion lead to a healthier financial system: as hinted, it will likely have long run positive impacts on the banks, since their long term business will be better

65 Breman, J. G., 2018, Eliminating Poor Quality Medicines: "Caveat Emptor, Caveat Venditor" (buyer beware, seller beware), International Health, Vol. 10, No. 5, pp. 321-323, (discussing information asymmetry: in transactions where a truly lacks knowledge of defects of underlying products, the seller ought to be held at a higher account).

66 Haim, L., 2013, p. 65.

67 Ibid., p. 66.

68 Cremer, D. de, 2015, Why Our Confidence in Banks Hasn't Been Restored, Harvard Business Review, (https://hbr.org/2015/03/why-our-trust-in-banks-hasnt-been-restored, 10. 9. 2020): Cremer, explained that "both competence and integrity are recurring themes in many discussions concerning the financial crisis. Benevolence, however, is not used very often - if at all. At the same time, banking clients particularly express concerns about whether the bank cares about their interests as well as its own interests. Put simply, a certain 'morality of care' is missing in the discussion. As a consequence, it also seems to be missing from efforts to restore trust in banks." 
guaranteed if consumers do not lose their finances as a result of poor decisions. Similarly, as Apaam et al noted, the increment in consumer trust will likely encourage the unbanked population to join the mainstream banking, ${ }^{69}$ and this will likely increase the capital of financial institutions, increase their profits, and perhaps reduce the propensity to increase product prices.

In addition to the protective measures suggested above on how to improve regulation and consumer wellbeing, courts can begin to apply the concept of constructive trust as a disgorgement tool when addressing the losses incurred by financial consumers as a result of being tricked to consume complex/shrouded financial products that were sold to them in deceptive manners. In that case, as Tajti has expounded, the extent to which the losses can be assessed as having been obtained by deception, can be deemed as being held in trust for the consumers by the financial institution. ${ }^{70}$

\section{CONCLUSION: A STRONGER NEED TO REINFORCE EXISTING PROTECTIVE MEASURES}

It is undeniable that most legal systems, in relation to commerce, developed more favorably around the activities of trading merchants and corporations who usually influenced the making of laws and policies to their advantage: this is now popularly known as 'regulatory capture'. Since corporations produce goods and services to ultimately serve consumers, it is important to protect the consumers from unfair and unconscionable practices, by as much as possible, interpreting consumer laws suspected to have been captured by corporations in a manner that is ultimately beneficial to the body of consumers. In a democracy, lawmakers are considered as agents of the citizens that voted them into power to make laws for the latter's wellbeing. Every consumer law statute in that sense is a beneficial legislation: thus if a literal interpretation of any part of it functionally benefits financial institutions but results into hardship to the consumers, then it will be safe to conclude that a regulatory capture has occurred and thus absurd. A fair minded court in the circumstance should therefore proceed to interpret purposively, in a way that benefits the consumers.

In view of the inadequate protective measures available to financial consumers, some legal systems that are yet to incorporate the concept of 'class action', (e.g., in the European Union), are encouraged to do so: consumer transactions have increased in volume, and typically transcend national borders due to the

69 Apaam, G. et al., 2017, FDIC National Survey of Unbanked and Underbanked Households, Federal Deposit Insurance Corporation, p. 4, (https://www.fdic.gov/householdsurvey/2017/2017report.pdf): The authors explained that "almost one-third (30.2 percent) of unbanked households cited 'Don't trust banks' as a reason for not having an account, the second-most commonly cited reason".

70 Tajti, T., 2019, p. 16: "the victims of fraud could also be prepaying consumers. The property subject to a constructive trust does not become part of the bankruptcy estate and hence is to be given back to creditors to the benefit and protection of whom the trust was imposed by the court. Therefore, the prepaying consumer-creditor would get the asset itself instead of the minimal recovery as an unsecured creditor." 
advent of the Internet. Also, in appropriate cases, banks and financial institutions should be disgorged of the dishonest profits made through sales of shrouded and deceptive products to consumers: contrary to the privity rule of contract, it should be possible for a consumer to institute a class action that will benefit other consumers who suffered similar deceptions, and regulators and courts in that regard should ensure that whatever sums that are paid out by banks and financial institutions as damages/fines respectively do not indirectly get transferred to consumers or written off in taxes.

Lastly, it is recommended that the laws that establish consumer protection bureaus should disable the directors/officers of such bureaus from having the power to accept gifts from any individual or company: the power to receive gifts could be an entry point of receiving bribes from financial institutions which they could characterize as gifts/Trojan horses to ensure regulatory capture. Corporate bribing (lobbying) of lawmakers should also be seen for what it is, as being the umbilical cord that links consumer abuses with the machinations of financial/ corporate institutions. Consumer bureaus should fund their activities exclusively from the taxpayers' monies to ensure independence and enhance their ability to carry out their regulatory duties without any fear or favor, including a severance of the umbilical cord.

\section{BIBLIOGRAPHY}

1. Albino, D., Hu, A., Bar-Yam, Y., 2013, Corporations and Regulators, the Game of Influence in Regulatory Capture, Working Paper, (https://arxiv.org/pdf/1310.0057.pdf, 10. 7. 2020).

2. Anderson, K. B., 2016, Mass-Market Consumer Fraud: Who Is Most Susceptible to Becoming a Victim? (https:/www.ftc.gov/system/files/documents/reports/mass-market-consumer-fraud-who-most-susceptible-becoming-victim/working_paper_332. pdf, 10. 9. 2020).

3. Apaam, G. et al., 2017, FDIC National Survey of Unbanked and Underbanked Households, Federal Deposit Insurance Corporation, (https://www.fdic.gov/householdsurvey/2017/2017report.pdf).

4. Bar-Gill, O., 2006, Bundling and Consumers Misperception, University of Chicago Law Review, Vol. 73, No. 1.

5. Bar-Gill, O., 2012, Seduction by Contract: Law, Economics, and Psychology in Consumer Markets, London, Oxford University Press.

6. Bar-Gill, O., Warren, E., 2008, Making Credit Safer, University of Pennsylvania Law Review, Vol. 157, No. 1, (https://www.law.upenn.edu/live/files/112-bargillwarren157upalrev12008pdf).

7. Ben-Shahar, O., Schneider, C. E., 2011, The Failure of Mandated Disclosure, University of Pennsylvania Law Review, Vol. 159, (https://www.law.upenn.edu/journals/ lawreview/articles/volume159/issue3/BenShaharSchneider159U.Pa.L.Rev.647(2011). pdf, 10. 6. 2020).

8. Bradgate, R., 2000, Commercial Law, London, Butterworths.

9. Breman, J. G., 2018, Eliminating Poor Quality Medicines: "Caveat Emptor, Caveat Venditor" (buyer beware, seller beware), International Health, Vol. 10, No. 5. 
10. Campbell, J. Y. et al., 2010, The Regulation of Consumer Financial Products: An Introductory Essay with Four Case Studies, Faculty Research Working Paper Series, (https://research.hks.harvard.edu/publications/getFile.aspx?Id=602, 9. 8. 2020).

11. Charter of Fundamental Rights of the European Union.

12. Chianu, E., 2007, The Horse and the Ass Yoked: Legal Principles to aid the Weak in a World of Unequals, $91^{\text {st }}$ Inaugural Lecture Series, University of Benin, (http://www. nigerianlawguru.com/articles/jurisprudence/THE\%20HORSE\%20AND\%20ASS\%20 YOKED,LEGAL\%20PRINCIPLES\%20TO\%20AID\%20THE\%20WEAK\%20IN\%20 A\%20WORLD\%20OF\%20UNEQUALS.pdf, 20. 8. 2020).

13. Cohen, J., 1982, History of Imprisonment for Debt and Its Relation to the Development of Discharge in Bankruptcy, Journal of Legal History, Vol. 3, No. 2.

14. Cole, S., Shastry, G. K., 2008, If You Are So Smart, Why Aren't You Rich? The Effects of Education, Financial Literacy and Cognitive Ability on Financial Market Participation, Working Paper 09-071 Harvard Business School, (https://www.econbiz.de/Record/if-you-are-so-smart-why-aren-t-you-rich-the-effects-of-educationfinancial-literacy-and-cognitive-ability-on-financial-market-participation-coleshawn/10003788911, 10. 8. 2020).

15. Cornish, W. R., Clark G. N., 1989, Law and Society in England 1750-1950, London, Sweet \& Maxwell, Chap. 2.

16. Crawford, B., 2013, Financial-Consumer Complaint Agencies, Canadian Business Law Journal, Vol. 54, No. 1.

17. Cremer, D. de, 2015, Why Our Confidence in Banks Hasn’t Been Restored, Harvard Business Review, (https://hbr.org/2015/03/why-our-trust-in-banks-hasnt-been-restored, 10. 9. 2020).

18. DellaVigna, S., Malmendier, U., 2004, Contract Design and Self-Control: Theory and Evidence, Quarterly Journal of Economics, Vol. 119, No. 2.

19. Ellison, G., 2005, A Model of Add-On Pricing, Quarterly Journal of Economics, Vol. 120, No. 2.

20. Emmons, W. R., 2005, Consumer-Finance Myths and Other Obstacles to Financial Literacy, Saint Louis University Public Law Review, Vol. 24, No. 2.

21. Federal Trade Commission: 'Consumer Finance', (https://www.ftc.gov/news-events/ media-resources/consumer-finance, 8. 8. 2020).

22. Financial Literacy and Education Commission, 2016, Promoting Financial Success in the United States: National Strategy for Financial Literacy, p. 7, (https://www.treasury.gov/resource-center/financial-education/Documents/National\%20Strategy\%20 for\%20Financial\%20Literacy\%202016\%20Update.pdf, 20. 7. 2020).

23. Gabaix, X., Laibson, D., 2006, Shrouded Attributes, Consumer Myopia, and Information Suppression in Competitive Markets, Quarterly Journal of Economics, Vol. 121, No. 2.

24. Gang Z., Guangzi L., 2017, Consumer Finance and Its Significance, in: Wang G., Zeng G., Xiaoying X., (eds) Development of Consumer Finance in East Asia, New York, Palgrave Macmillan.

25. Gikay, A. A., 2019, European Consumer Law and Blockchain Based Financial Services: A Functional Approach Against the Rhetoric of Regulatory Uncertainty, Tilburg Law Review, Vol. 24, (http://doi.org/10.5334/tilr.135).

26. Haim, L., 2013, Rethinking Consumer Protection Policy in Financial Market, Journal of Law and Commerce, Vol. 32, No. 1. 
27. Hamilton, W. H., 1931, The Ancient Maxim Caveat Emptor, Yale Law Journal, Vol. 40, No. 8, (https://digitalcommons.law.yale.edu/cgi/viewcontent.cgi? article=3488\&context $=y l j)$.

28. Hempling, S., 2013, Regulatory Capture: Sources and Solutions, Emory Corporate Governance and Accountability Review, (https://law.emory.edu/ecgar/content/volume-1/issue-1/essays/regulatory-capture.html, 10. 10. 2020).

29. Howcroft, B., Hewer, P., Hamilton, R., 2003, Consumer Decision-Making Styles and the Purchase of Financial Services, The Service Industries Journal, Vol. 23, No. 3.

30. Iyengar, S. S., Lepper, M. R., 2000, When Choice is Demotivating: Can One Desire Too Much of a Good Thing?, Journal of Personality \& Social Psychology, Vol. 79.

31. Jager, C. E. de, 2017, A Question of Trust: the Pursuit of Consumer Trust in the Financial Sector by Means of EU Legislation, Journal of Consumer Policy, Vol. 40, No. 3.

32. J. Spurling Ltd. v. Bradshaw [1956] 1 WLR 461, 466.

33. Kiser, E. K., 2002, Household Switching Behavior at Depository Institutions: Evidence from Survey Data 8, Federal Reserve Board, Financial \& Economic Discussion Series, Working Paper No. 44, (https://www.federalreserve.gov/pubs/feds/2002/200244/200244pap.pdf, 9. 8. 2020).

34. Klemperer, P., 1987, Markets with Consumer Switching Costs, The Quarterly Journal of Economics, Vol. 102, No. 2.

35. Ko, K. J., Williams, J., 2013, The Effects of Regulating Penalty Fees for Consumer Financial Products, Sec. \& Exch. Comm'n Div. of Risk, Strategy \& Fin. Innovation, Working Paper No. 3, (http://papers.ssrn.com/sol3/papers.cfm?abstract_id=2122793, 10. 8. 2020).

36. Kraninger, K. L., 2018, Consumer Financial Protection Bureau. Consumer Response Annual Report, (https://files.consumerfinance.gov/f/documents/cfpb_consumer-response-annual-report_2018.pdf, 23. 7. 2020).

37. Kumar, A., Gilovich, T., 2016, To Do or to Have, Now or Later? The Preferred Consumption Profiles of Material and Experiential Purchases, Journal of Consumer Psychology, Vol. 26, No. 2.

38. Lacko, J. M., Pappalardo, J. K., 2010, The Failure and Promise of Mandated Consumer Mortgage Disclosures: Evidence from Qualitative Interviews and a Controlled Experiment with Mortgage Borrowers, American Economic Review, Vol. 100, (https:// pdfs.semanticscholar.org/352a/736e64ce16aa0ee97be0eb2e0d1fc3acc48d.pdf, 10.7. 2020).

39. Lusardi, A., Mitchell, O. S., 2007, Financial Literacy and Retirement Preparedness: Evidence and Implications for Financial Education Programs, Business Economics, (https://www.dartmouth.edu/ alusardi/Papers/Financial_Literacy.pdf, 8. 8. 2020).

40. Lusardi, A., Mitchell, O. S., 2014, The Economic Importance of Financial Literacy: Theory and Evidence, Journal of Economic Literature, Vol. 52, No. 1.

41. Mann, R. J., 2012, After the Great Recession: Regulating Financial Services for Lowand Middle-Income Communities, Washington \& Lee Law Review, Vol. 69, 729, (https://scholarlycommons.law.wlu.edu/wlulr/vol69/iss2/8/).

42. Mathilde, P., 2017, Regulatory Capture in Financial Supervision, in: Douady, R., Goulet, C., Pradier, P. C. (eds.) Financial Regulation in the EU, Palgrave Macmillan, Cham.

43. Meier, S., Sprenger, C., 2010, Present-Biased Preferences and Credit Card Borrowing, American Economic Journal: Applied Economics, Vol. 2, No. 1. 
44. Melecky, M., Rutledge, S., 2016, Financial Consumer Protection and the Global Financial Crisis, MPRA Paper No. 28201, p. 2, (https://mpra.ub.uni-muenchen. de/28201/1/MPRA_paper_28201.pdf, 10. 9. 2020).

45. Nalebuff, B., 2003, Bundling, Tying, and Portfolio Effects, DTI Economics Paper, No. 1, (https://www.immagic.com/eLibrary/ARCHIVES/GENERAL/UK_DTI/ T030207D.pdf, 8. 8. 2020).

46. Nilsson, J., Nordvall, A. C., Isberg, S., The Information Search Process of Socially Responsible Investors, in: Harrison, T., (eds.), 2016, Financial Literacy and the Limits of Financial Decision-Making, London, Palgrave Macmillan, Cham.

47. O’Donoghue, T., Rabin, M., 1999, Doing It Now or Later, American Economic Review, Vol. 89, No. 1.

48. Obama, B., Remarks by the President at Signing of Dodd-Frank Wall Street Reform and Consumer Protection Act, The White House, July 21 2010, (https://obamawhitehouse.archives.gov/the-press-office/remarks-president-signing-dodd-frank-wallstreet-reform-and-consumer-protection-act, 10. 8. 2020).

49. Schwartz, A., Grether, D. M., Wilde, L. L., 1986, Irrelevance of Information Overload: An Analysis of Search and Disclosure, Southern Californian Law Review, Vol. 59, (https://digitalcommons.law.yale.edu/cgi/viewcontent.cgi? article=2099\&contex$\mathrm{t}=$ fss_papers).

50. Simpson, W. B., 1975, A History of the Common Law of Contract: The Rise of the Action of Assumpsit, New York, Oxford University Press.

51. Stănescu, C. G., 2019, The Responsible Consumer in the Digital Age: On the Conceptual Shift from 'average' to 'responsible' Consumer and the Inadequacy of the 'information Paradigm' in Consumer Financial Protection, Tilburg Law Review, Vol. 24, No. 1, (https://tilburglawreview.com/articles/10.5334/tilr.143/, 10. 7. 2020).

52. Tajti, T., 2019, Unprotected Consumers in the Digital Age: The Consumer-creditors of Bankrupt, Abandoned, Defunct and of Zombie Companies, Tilburg Law Review, Vol. 24, No. 1, (http://doi.org/10.5334/tilr.139).

53. The Harris Poll, 2019, Consumer Financial Literacy Survey, (https://www.nfcc.org/ resources/client-impact-and-research/2019-consumer-financial-literacy-survey/, 17. 7. 2020).

54. Title X of the Dodd-Frank Wall Street Reform and Consumer Protection Act, 2010.

55. Tolmie, F., 2003, Corporate and Personal Insolvency, $2^{\text {nd }}$ ed., London, Cavendish Publishing.

56. Treaty of the Functioning of the European Union.

57. Truth in Lending Act.

58. Turgeon, E. N., 2008, Boom and Bust for Whom: The Economic Philosophy behind the 2008 Financial Crisis, Virginia Law \& Business Review, Vol. 4, No. 1.

59. Velasco, J., 2010, Shareholder ownership and primacy, University of Illinois Law Review, 897 at 944, (https://scholarship.law.nd.edu/cgi/viewcontent.cgi?article=1331\&context=law_faculty_scholarship).

60. Willis, L. E., 2009, Against Financial Literacy Education, Iowa Law Review.

61. Xavier, G., Laibson, D., 2006, Shrouded Attributes, Consumer Myopia, and Information Suppression in Competitive Markets, Quarterly Journal of Economics, Vol. 121, No. 2.

62. Xclusive Plus, (https://www.accessbankplc.com/XclusivePlus, 23. 7. 2020). 


\title{
PREISPITIVANJE EFIKASNOSTI POLITIKA I MERA ZAŠTITE POTROŠAČA NA FINANSIJSKOM TRŽIŠTU
}

\author{
Williams C. Iheme
}

\section{REZIME}

U ovom radu se identifikuje i preispituje učestala praksa finansijskih institucija u dizajniranju i prodaji složenih finansijskih proizvoda potrošačima koji nisu u stanju da ih u potpunosti razumeju, pa stoga ni da donose odluke utemeljene na dobroj informisanosti pre kupovine. Obmanjivanje potrošača, zbog čega oni nehotice kupuju složene finansijske proizvode, generalno uzrokuje da oni trpe finansijske gubitke, što dodatno izaziva niz negativnih efekata u društvu. U radu se razmatraju razlozi zbog kojih su finansijske institucije motivisane da prodaju složene finansijske proizvode i napominje kako se njihov uspeh u tom pogledu, između ostalog, održava zbog neadekvatnosti pravnih regulatornih sistema. Ugovorno pravo je identifikovano kao pomoć u stvaranju plodnog tla zahvaljujući slobodi ugovaranja i pravilu Caveat emptor, koji dovode do toga da zloupotrebe prema potrošačima korisnicima finansijskih usluga regulatorni organi često ne primete ili ne cene, zbog čega se od potrošača zahteva da se u velikoj meri oslanjanju na sebe. U radu se ukazuje na slabosti tipičnih mera politike protiv eksploatacije i na iskrivljena pravila obelodanjivanja koja u velikoj meri razumevanje složenih finansijskih proizvoda prepuštaju potrošačima ne uzimajući u obzir mahinacije finansijskih institucija ka smanjenju razumevanja: većina brošura o finansijskim informacijama puna je finansijske terminologije i pisana komplikovanim jezikom, a istovremeno se zadovoljavaju zakonski zahtevi informisanja.

U radu se predlaže novi oblik pravila informisanja zasnovan na konceptima upozorenja dobavljača i contra proferentem, koji bi, prema tome, trebalo da zahtevaju prezentaciju informacija od finansijske institucije protiv sopstvenih interesa i nedvosmislenu prezentaciju nedostataka uz navođenje prednosti proizvoda koji nude svojim potrošačima. $U$ radu se dalje tvrdi da bi glavna uloga regulatora i sudova u datim okolnostima trebalo da bude nadgledanje i procena nivoa usklađenosti i, prema tome, izdavanje godišnjeg sertifikata o učinku koji finansijske institucije moraju vidljivo objaviti na svojim veb stranama i mestima poslovanja i uključiti ih u informativne letke u kojima su opisali svoje proizvode, tako da potrošači na prvi pogled mogu znati koje finansijske institucije jesu, odnosno nisu naklonjene potrošačima.

Dalje, većina pravnih sistema (u vezi s trgovinom) razvijala se fokusirajući se na potrebe i probleme trgovaca i korporacija koji su obično uticali na donošenje zakona i politika u svoju korist: ovo je danas popularno poznato kao „regulatorno hvatanje propisa“. Pošto korporacije proizvode robu i usluge da bi na kraju služile potrošačima, važno je zaštititi potrošače od nepravičnih i nepoštenih praksi, što je više moguće, tumačeći potrošačke zakone, za koje se sumnja da su zarobljeni od strane korporacije, na način koji suštinski služi interesima potrošača. U demokratiji se zakonodavci smatraju zastupnicima građana koji su ih izabrali kao vlast da donose zakone za dobrobit potonjih. Svaki zakon o zaštiti potrošača u tom smislu je korisno zakonodavstvo: stoga ako doslovno tumačenje bilo kog njegovog dela funkcionalno koristi finansijskim institucijama, ali rezultira poteškoćama za potrošače, tada bi se moglo sa sigurnošću zaključiti da je došlo do „regulatornog hvatanja“ i time apsurda. Nepristrasni sud u datim okolnostima bi stoga trebalo da nastavi sa tumačenjem namenski, na način koji je u korist potrošača. 
S obzirom na neadekvatne zaštitne mere koje su dostupne potrošačima korisnicima finansijskih usluga, neki pravni sistemi koji još uvek nisu prihvatili koncept „kolektivne tužbe“" (npr. u Evropskoj uniji) trebalo bi da to učine posebno zato što je broj potrošačkih transakcija povećan i da prelaze nacionalne granice zbog pojave interneta. Takođe, u odgovarajućim slučajevima, bankama i finansijskim institucijama treba oduzeti dobit nečasno ostvarenu prodajom proizvoda čije su karakteristike netransparentne ili prikrivene i proizvoda kojima se obmanjuju potrošači: suprotno pravilu privatnosti ugovora, potrošaču treba omogućiti pokretanje kolektivne tužbe od koje će imati koristi drugi potrošači koji su pretrpeli slične obmane, i regulatori i sudovi u tom pogledu treba da obezbede da se bilo koji iznosi koje banke ili finansijske institucije isplate kao odštetu/ novčanu kaznu javno prenesu potrošačima ili otpišu porezom.

Autor preporučuje da zakoni kojima se uspostavljaju biroi za zaštitu potrošača onemoguće direktore/službenike takvih biroa da imaju mogućnost da prihvate poklon od bilo kog pojedinca ili kompanije: mogućnost primanja poklona mogla bi biti polazna tačka primanja mita od finansijskih institucija koje bi ih mogle okarakterisati kao poklone (trojanski konji) kako bi osigurali regulatorno hvatanje propisa. Podmićivanje (lobiranje) zakonodavaca od strane preduzeća takođe treba shvatiti na pravi način, kao pupčanu vrpcu koja povezuje zloupotrebe na račun potrošača sa mahinacijama finansijskih/ korporativnih institucija. Tela za zaštitu potrošača treba da finansiraju svoje aktivnosti isključivo iz državnog budžeta kako bi osigurali nezavisnost i poboljšali svoju sposobnost da izvršavaju svoje regulatorne dužnosti bez ikakvog straha i naklonosti, uključujući raskidanje spomenute pupčane vrpce.

Ključne reči: potrošači korisnici finansijskih usluga, obelodanjivanje, sloboda ugovaranja, caveat emptor, caveat venditor, složeni proizvodi, regulatorno hvatanje propisa. 